\title{
Original article \\ Comparative evaluation of hepatoprotective efficacy of Terminalia chebula Retz. and Terminalia belerica (Gaertn.) Roxb. fruits extracts in rat model
}

\author{
Neelam Kushwaha, Deba Brata Mondal and Karam Pal Singh* \\ Division of Medicine, ICAR-Indian Veterinary Research Institute, Izatnagar-243 122, Uttar Pradesh, India \\ *Centre for Animal Disease Research and Diagnosis, ICAR-Indian Veterinary Research Institute, Izatnagar-243 122, Uttar Pradesh, India
}

Received July 5, 2017: Revised August 25, 2017: Accepted August 30, 2017: Published online December 30, 2017

\begin{abstract}
Use of herbs or herbal extracts is new therapeutic approach to minimize liver damage. Hepatoprotective efficacy of the ethanolic extracts of fruits of Terminalia chebula Retz. and Terminalia belerica (Gaertn.) Roxb. of Combretaceace family was studied at different doses in Albino Wistar rats against carbon tetrachloride $\left(\mathrm{CCl}_{4}\right)$ induced hepatotoxicity. Administration of $\mathrm{CCl}_{4}$ resulted in significant elevation of liver weight and liver volume as well as serum alanine amino transferase, aspartate amino transferase, alkaline phosphatase, bilirubin and blood urea nitrogen level. The rats treated with T. chebula @ $200 \mathrm{mg} / \mathrm{kg}$ body weight showed mild degree of fatty changes with early degenerative changes in liver. Treatment with ethanolic extract of $T$. belerica prevented degenerative changes and macrovesicular steatosis induced by $\mathrm{CCl}_{4}$, and stimulated regeneration of hepatocytes. The study revealed that $T$. belerica had good hepatoprotective effect against $\mathrm{CCl}_{4}$ induced hepatotoxicity based on morphology as well as histopathology of liver and serum hepatic enzyme analysis. Therefore, T. belerica fruits might offer new alternatives to the limited therapeutic options for patients with compromised liver conditions.
\end{abstract}

Key words: Terminalia belerica Retz., Terminalia chebula (Gaertn.) Roxb., carbon tetrachloride, hepatoprotective, in vivo

\section{Introduction}

Liver plays vital role in the maintenance, performance and regulating homeostasis of the body. It is involved in all the biochemical pathways of growth, digestion, nutrient supply, energy provision and reproduction (Ward and Daly, 1999). Therefore, maintenance of a healthy liver is essential for the overall well being of an individual. Each liver disease has its own specific treatment regimen. Disease directed intervention may vary with different etiological agents though all leads to hepatopathy. Since time immemorial, mankind has made the use of plants in the treatment of various ailments. Medicinal plants are valuable and cost-effective source of unique phytoconstituents, and are used extensively in the development of drugs against various diseases (Gupta, 2012; Sarasa et al., 2012). Around 35,000-70,000 species of plants have been used in medicine, neutraceuticals and/or cosmetic purpose (Shanti et al., 2010). Popularity of herbal drugs is increasing all over the world day-by-

\footnotetext{
Author for correspondence: Dr. Neelam Kushwaha

Division of Medicine, ICAR-Indian Veterinary Research Institute, Izatnagar-243 122, Uttar Pradesh, India

Present Address: Hospital Registrar, College of Veterinary and Animal Sciences, Udgir-413517, Maharashtra, India

E-mail: kushneils@gmail.com

Tel.: +91-8283804225
}

Copyright @ 2017 Ukaaz Publications. All rights reserved.

Email: ukaaz@yahoo.com; Website: www.ukaazpublications.com day because of their lesser side effects as compared to synthetic drugs (Rout et al., 2012). Traditional plant based remedies are still the first choice in the developing countries and in great demand in the developed world for primary health care (Ayyanar and Ignacimuthu, 2011; Majeed, 2017).

Use of herbs, herbal extracts or plant derived drugs is a new therapeutic approach to treat different diseases (Joshi and Dhavan, 2005) and herbal alternatives are one of the best ways to minimize liver damage. A large number of plants and formulations have been claimed to have hepatoprotective activity. In spite of tremendous strides in medicine, there are hardly any drugs that stimulate liver function, offer protection to the liver from damage or help regeneration of hepatic cells (Chaterjee, 2000). Therefore, due importance has been given globally to develop plant based hepatoprotective drugs (Bone and Mills, 2001). Silymarin and phosphatidylcholine are reported as hepatoprotector in rats (Eminzade et al., 2008; Podobed et al., 1995). Fruits of T. chebula and T. belerica of Combretaceace family are widely used in the Indian traditional system of medicine (Chopra et al., 1956). T. chebula is commonly known as black myroblans in english and harad in hindi, has been extensively used in ayurveda, unani and homeopathy medicine and have been used as traditional medicines as house hold remedy (Chattopadhyay and Bhattacharyya, 2007). T. belerica also referred to as, beleric myrobalan in english, bibhitaki in sanskrit, locally known as bahera in India, has been used for centuries in the ayurveda (Indian Herbal 
Pharmacopoeia, 2002). The present study was aimed to evaluate comparative hepatoprotective efficacy of ethanolic extract of fruits of $T$. chebula and $T$. belerica against carbon tetrachloride $\left(\mathrm{CCl}_{4}\right)$ induced hepatotoxicity in experimental rats.

\section{Materials and Methods}

The phytochemical analysis and antioxidant properties of aqueous as well as ethanolic extracts of Brassica oleracea (flouresece), Terminalia chebula (fruits), Terminalia belerica (fruits), Phyllanthus emblica (fruits), Abutilon indicum (stems and leaves) and Swertia chirata (stems) were studies in vitro. In vitro qualitative and quantitative phytochemical analysis of these selected plant materials revealed potent antioxidant activity in ethanolic extracts of $T$. belerica and T. chebula (Kushwaha et al., 2017). Therefore, ethanolic extracts of both were taken for in vivo study to assess their hepatoprotective efficacy.

\subsection{Preparation of plant extracts}

Fruits (fully ripened) of $T$. chebula and T. belerica were collected from and around Bareilly (U.P.) region, air dried and grinded to mesh for preparation of plant extracts. The fruits of the plants were authenticated by Dr. R.B. Allapur, Department of Botany, Maharashtra Udaygiri Mahavidyalay, Udgir, Maharashtra, India as Terminalia chebula (Family Combretaceace) and Terminalia belerica (Family Combretaceace) and specimen copies of the samples were preserved in the herbarium of the Department of Botany, Maharashtra Udaygiri Mahavidyalay, Udgir with the specimen No. 01 and 02, respectively. One specimen copy of both the fruits was also sent to Botanical Survey of India (BSI), Pune, Maharashtra, India for future reference. A $100 \mathrm{gm}$ powder samples were placed in coloumner soxhlet extraction system and extracted by using absolute ethanol. Collected extracts were dried on hot plate till the solvent got evaporated. The extracts were stored in tightly closed container at $-20^{\circ} \mathrm{C}$ for further use. The ethanolic extracts were dissolved separately in distilled water by the help of magnetic stirrer.

\subsection{Treatment protocol}

Forty two Albino Wistar male rats (100-150 gm) of 3-4 weeks of age and their standard diet were obtained from Laboratory Animal Resource Section of ICAR-Indian Veterinary Research Institute (IVRI), Izatnagar, Uttar Pradesh, India. All rats were fed on the standard diet, and water was provided ad libitum. They were kept in experimental animal shed of Division of Medicine, IVRI under standard managemental condition (50-60\% humidity, $20-25^{\circ} \mathrm{C}$ temperature and $12 \mathrm{~h}$ light and $12 \mathrm{~h}$ dark cycle) for 7 days before starting the experiment for acclimatization. Rats were divided randomly into seven groups having six rats in each group as follows:

Group I : Negative control group: Rats were fed on standard diet for 4 weeks.

Group II : Positive control group: Rats were given $\mathrm{CCl}_{4}$ mixed with olive oil (1:1, v/v) @ 4 ml/kg body weight per os (p.o.) twice a week for 4 weeks.

Group III : Standard group: Rats were given silymarin (MP Biomedicals, Navi Mumbai, Maharashtra) @ $5 \mathrm{mg} / \mathrm{kg}$ body weight (p.o.) daily with olive oil and $\mathrm{CCl}_{4}$ as group II for 4 weeks.
Group IV : Test group: Rats were given T. chebula extract @ 100 $\mathrm{mg} / \mathrm{kg}$ body weight (p.o.) daily with olive oil and $\mathrm{CCl}_{4}$ as group II for 4 weeks.

Group V : Test group: Rats were given T. chebula extract @ 200 $\mathrm{mg} / \mathrm{kg}$ body weight (p.o.) daily with olive oil and $\mathrm{CCl}_{4}$ as group II for 4 weeks.

Group VI : Test group: Rats were given T. belerica extract @ 100 $\mathrm{mg} / \mathrm{kg}$ body weight (p.o.) daily with olive oil and $\mathrm{CCl}_{4}$ as group II for 4 weeks.

Group VII : Test group: Rats were given T. belerica extract @ 200 $\mathrm{mg} / \mathrm{kg}$ body weight (p.o.) daily with olive oil and $\mathrm{CCl}_{4}$ as group II for 4 weeks.

Hepatotoxicity was induced in all groups except negative control group by administering $\mathrm{CCl}_{4}$ mixed with olive oil (1:1, v/v) @ $4 \mathrm{ml} /$ $\mathrm{kg}$ body weight orally twice a week for four weeks (Doi et al., 1991). At the end of experiment, $3 \mathrm{ml}$ of blood was collected directly from heart of all rats in clean, sterile, non-heparinised vial for serum separation and, rats were sacrificed as per Committee for the Purpose of Control and Supervision of Experiments on Animals (CPCSE) norms (IAEC/CPCSEA vide office letter No. F. 1-53/2012 -13 -JD (Res) dated 10/09/13 of Joint Director (Research), ICAR-IVRI, Izatnagar) and liver samples were collected for histopathological study. Blood samples were immediately centrifuged at $3000 \mathrm{rpm}$ for 15 min to separate serum. Serum collected was kept in deep freeze at $-20^{\circ} \mathrm{C}$ until biochemical analysis.

\subsection{Biochemical analysis}

Alanine amino transferase (ALT), aspartate amino transferase (AST), alkaline phosphatase (ALP), total protein, albumin, total bilirubin, blood urea nitrogen (BUN) and creatinine were estimated in serum by commercially available kits (Span Diagnostics and Sigma).

\subsection{Histopathological examination}

Liver of the sacrificed rats were taken and then excised quickly and immersed in $10 \%$ formalin solution. The fixed specimens were then trimmed, processed and stained with hematoxylin and eosin stains (Culling, 1963) and was observed under microscope for degeneration, fatty changes or necrotic changes.

\subsection{Statistical analysis}

The obtained results were expressed as mean \pm SE (standard error). Data were evaluated statistically with computerized SPSS package program (SPSS 9.00 software) using one-way analysis of variance (ANOVA). Significant differences among means were estimated at $p<0.05$ according to Snedecor and Cochran (1994).

\section{Results and Discussion}

The present study aimed to investigate the comparative hepatoprotective efficacy of ethanolic extract of fruits of T. chebula and $T$. belerica against $\mathrm{CCl}_{4}$ induced hepatotoxicity in experimental rats. Carbon tetrachloride $\left(\mathrm{CCl}_{4}\right)$ is one of the oldest and most widely used chemical for experimental induction of liver toxicity in laboratory animals (Alhassan et al., 2009) and is a commonly used model for the evaluation of hepatoprotective drugs (Ahsan et al., 2009; Naskar et al., 2011). All the rats were monitored closely for clinico-physical changes if any during entire experiment. However, no physical changes were recorded except alteration in their body weight gain/ 
loss in all seven groups. Mean \pm SE of alterations in body weights of rats at weekly intervals is shown in Table 1 . There was no significant $(p<0.05)$ difference in body weight of all seven groups at the day 0 , i.e., beginning of experiment. Steady increase in body weight was recorded all groups of rats except positive control group (Figure 1). The same trend has been observed by Gurav (2010). Significant $(p<0.05)$ increase in body weight was observed in group VII, whereas significant $(p<0.05)$ loss in body weight was recorded in group II. Animals having the liver injury can lose body weight and daily activity (Ray and Mehendale, 1990). The liver weights as well as volumes were significantly $(p<0.05)$ lowered in the rats treated with ethanolic extract of T. belerica fruits.

Table 1: Alteration in body weight $(\mathrm{g})$ in rats received different treatment (mean $\pm \mathrm{SE})$

\begin{tabular}{|l|c|c|c|c|c|}
\hline Groups $(\mathbf{n = 6})$ & day 0 & day 7 & day 14 & Day 21 & Day 28 \\
\hline Group I & $160.00 \pm 5.16$ & $168.33 \pm 6.66$ & $175.83 \pm 6.24$ & $182.50 \pm 6.02$ & $184.16 \pm 6.24$ \\
Group II & $164.16 \pm 7.12^{\mathrm{bc}}$ & $170.00 \pm 4.65^{\mathrm{c}}$ & $164.16 \pm 4.54^{\mathrm{bc}}$ & $150.83 \pm 2.38^{\mathrm{ab}}$ & $141.66 \pm 2.47^{\mathrm{a}}$ \\
Group III & $165.83 \pm 3.74$ & $170.00 \pm 5.16$ & $172.50 \pm 6.55$ & $175.00 \pm 4.08$ & $177.50 \pm 5.28$ \\
Group IV & $165.83 \pm 5.54$ & $169.16 \pm 8.10$ & $164.16 \pm 8.50$ & $159.16 \pm 5.68$ & $148.33 \pm 7.14$ \\
Group V & $166.66 \pm 7.60$ & $171.66 \pm 7.60$ & $175.00 \pm 5.32$ & $177.50 \pm 5.88$ & $180.00 \pm 5.62$ \\
Group VI & $167.50 \pm 4.23$ & $170.83 \pm 5.83$ & $176.66 \pm 6.66$ & $180.83 \pm 5.54$ & $182.50 \pm 5.28$ \\
Group VII & $167.50 \pm 3.81^{\mathrm{a}}$ & $175.83 \pm 5.23^{\mathrm{ab}}$ & $183.33 \pm 6.54^{\mathrm{ab}}$ & $192.50 \pm 5.43^{\mathrm{b}}$ & $195.00 \pm 4.47^{\mathrm{b}}$ \\
\hline
\end{tabular}

Values bearing different superscripts in the same row differ significantly $(\mathrm{p}<0.05)$

Group I: Negative control; Group II: $\mathrm{CCl}_{4}+$ olive oil (1:1,v/v) @ 4 ml/kg; Group III: $\mathrm{CCl}_{4}+$ olive oil (1:1,v/v) @ 4 ml/ $\mathrm{kg}+$ silymarin @ $5 \mathrm{mg} / \mathrm{kg}$; Group IV: $\mathrm{CCl}_{4}+$ olive oil $(1: 1, \mathrm{v} / \mathrm{v}) @ 4 \mathrm{ml} / \mathrm{kg}+T$. chebula @ $100 \mathrm{mg} / \mathrm{kg} ; \mathrm{Group} \mathrm{V:} \mathrm{CCl}+$ olive oil (1:1,v/v) @ $4 \mathrm{ml} / \mathrm{kg}+$ T. chebula @ $200 \mathrm{mg} / \mathrm{kg}$; GroupVI: $\mathrm{CCl}_{4}+$ olive oil (1:1,v/v)@ $4 \mathrm{ml} / \mathrm{kg}+$ T. belerica @ $100 \mathrm{mg} / \mathrm{kg}$; GroupVII: $\mathrm{CCl}_{4}+$ olive oil $(1: 1, \mathrm{v} / \mathrm{v}) @ 4 \mathrm{ml} / \mathrm{kg}+$ T. belerica @ $200 \mathrm{mg} / \mathrm{kg}$.

Effect of various treatments on biochemical parameters of different groups is given in Table 2 . The significantly $(p<0.05)$ increased level of AST and ALT was observed in group II, followed by group IV and $\mathrm{V}$, whereas significantly $(p<0.05)$ decreased levels of AST and ALT was seen in group I, III, VI and VII. Significantly $(p<0.05)$ increased level of ALP was seen in group II only, compared to all other groups. Due to repeated doses of $\mathrm{CCl}_{4}$, there is leakage of enzymes like AST, ALT and ALP across hepatocellular membrane and in blood, indicating liver dysfunction and cellular injury (Paduraru et al., 1996; Muriel and Escobar, 2003). The AST and ALT level of group VII was comparable with group III. T. belerica fruits extract treatment caused significant drop in ALT and AST which is in accordance with the findings of Pingale (2011). Total protein was significantly $(p<0.05)$ higher in group I, followed by group V, whereas in group II and IV, it was decreased significantly $(p<0.05)$. Significantly $(p<0.05)$ higher value of albumin was observed in group I and VII, followed by group III and it was decreased significantly $(p<0.05)$ in group II and IV. A significant $(p<0.05)$ decrease in total protein and albumin in positive control group was found, which may be due to decreased protein synthesis in liver due to long term treatment with $\mathrm{CCl}_{4}$ (Patel et al., 2010). Total bilirubin was increased significantly $(p<0.05)$ in group II. Pingale (2011) has also reported that significantly increased plasma levels of bilirubin after treatment of $\mathrm{CCl}_{4}$. Significantly $(p<0.05)$ highest value of BUN was found in group II, followed by group IV, $\mathrm{V}$, VI, VII and III, whereas it was significantly $(p<0.05)$ lowest in group I. There was no significant $(p<0.05)$ variation in level of creatinine in all group of rats. Almost all biochemical parameters of silymarin treated group come near to negative control group, which is attributed to its antioxidant and free radicals scavenging properties (Ramadan et al., 2002). Rats treated with ethanolic extract of T. belerica fruits and silymarin had significantly lowered level of AST, ALT, ALP and total bilirubin, whereas albumin and total protein were increased significantly which is in agreement with other workers (Jain et al., 2008).

Table 2: Serum biochemical profile in different groups of rats (mean $\pm \mathrm{SE}$ )

\begin{tabular}{|c|c|c|c|c|c|c|c|c|}
\hline $\begin{array}{l}\text { Groups } \\
(n=6)\end{array}$ & $\begin{array}{c}\text { AST } \\
(\text { IU/L) }\end{array}$ & $\begin{array}{c}\text { ALT } \\
(\mathbf{I U} / \mathbf{L})\end{array}$ & $\begin{array}{c}\text { ALP } \\
(\mathbf{I U} / \mathbf{L})\end{array}$ & $\begin{array}{c}\text { Total } \\
\text { protein } \\
(\mathrm{g} / \mathrm{dl})\end{array}$ & $\begin{array}{l}\text { Albumin } \\
(\text { g/dl })\end{array}$ & $\begin{array}{c}\text { Total } \\
\text { bilirubin } \\
\text { (mg/dl) }\end{array}$ & $\begin{array}{c}\text { Blood urea } \\
\text { nitrogen } \\
(\mathrm{mg} / \mathrm{dl})\end{array}$ & $\begin{array}{l}\text { Creatinine } \\
\quad(\mathrm{mg} / \mathrm{dl})\end{array}$ \\
\hline Group I & $67.77 \pm 3.22^{\mathrm{a}}$ & $69.25 \pm 2.85^{\mathrm{a}}$ & $133.90 \pm 20.46^{\mathrm{a}}$ & $7.88 \pm 0.27^{\mathrm{c}}$ & $4.58 \pm 0.14^{\mathrm{c}}$ & $0.34 \pm 0.05^{\mathrm{a}}$ & $24.77 \pm 0.50^{\mathrm{a}}$ & $1.17 \pm 0.14$ \\
\hline Group II & $184.46 \pm 4.15^{\mathrm{d}}$ & $164.13 \pm 9.56^{c}$ & $246.79 \pm 5.38^{b}$ & $4.43 \pm 0.32^{\mathrm{a}}$ & $3.51 \pm 0.20^{\mathrm{a}}$ & $0.79 \pm 0.04^{\mathrm{b}}$ & $35.07 \pm 0.57^{\mathrm{d}}$ & $1.57 \pm 0.11$ \\
\hline Group III & $71.31 \pm 3.44^{\mathrm{a}}$ & $71.01 \pm 3.18^{\mathrm{a}}$ & $160.91 \pm 3.55^{\mathrm{a}}$ & $7.22 \pm 0.21^{\mathrm{bc}}$ & $4.02 \pm 0.09^{\mathrm{abc}}$ & $0.31 \pm 0.04^{\mathrm{a}}$ & $26.38 \pm 0.59^{\mathrm{ab}}$ & $1.20 \pm 0.09$ \\
\hline Group IV & $119.63 \pm 4.32^{\mathrm{c}}$ & $126.12 \pm 7.93^{b}$ & $171.31 \pm 3.39^{\mathrm{a}}$ & $4.89 \pm 0.17^{\mathrm{a}}$ & $3.75 \pm 0.16^{\mathrm{ab}}$ & $0.47 \pm 0.04^{\mathrm{a}}$ & $29.36 \pm 0.53^{c}$ & $1.52 \pm 0.05$ \\
\hline Group V & $98.12 \pm 5.26^{\mathrm{b}}$ & $107.26 \pm 6.11^{b}$ & $164.98 \pm 7.72^{a}$ & $6.76 \pm 0.04^{\mathrm{b}}$ & $4.43 \pm 0.05^{\mathrm{bc}}$ & $0.37 \pm 0.03^{\mathrm{a}}$ & $28.93 \pm 0.45^{\mathrm{bc}}$ & $1.30 \pm 0.10$ \\
\hline Group VI & $75.14 \pm 3.47^{\mathrm{a}}$ & $76.02 \pm 3.39^{a}$ & $158.20 \pm 4.63^{a}$ & $6.90 \pm 0.26^{b c}$ & $4.35 \pm 0.17^{\mathrm{bc}}$ & $0.41 \pm 0.05^{\mathrm{a}}$ & $27.02 \pm 0.72^{\mathrm{ab}}$ & $1.38 \pm 0.07$ \\
\hline Group VII & $72.19 \pm 3.75^{\mathrm{a}}$ & $72.19 \pm 4.86^{\mathrm{a}}$ & $154.58 \pm 3.77^{\mathrm{a}}$ & $7.73 \pm 0.18^{\mathrm{bc}}$ & $4.61 \pm 0.21^{\mathrm{c}}$ & $0.31 \pm 0.02^{\mathrm{a}}$ & $26.84 \pm 0.73^{\mathrm{ab}}$ & $1.25 \pm 0.096$ \\
\hline
\end{tabular}

Values bearing different superscripts in the same column differ significantly $(p<0.05)$

Group I: Negative control; Group II: $\mathrm{CCl}_{4}+$ olive oil (1:1,v/v) @ 4 ml/kg; Group III: $\mathrm{CCl}_{4}+$ olive oil (1:1,v/v) @ 4 ml/kg + silymarin @ 5 mg/kg; Group IV: $\mathrm{CCl}_{4}+$ olive oil $(1: 1, \mathrm{v} / \mathrm{v}) @ 4 \mathrm{ml} / \mathrm{kg}+$ T. chebula @ $100 \mathrm{mg} / \mathrm{kg}$; Group V: $\mathrm{CCl}_{4}+$ olive oil (1:1,v/v) @ $4 \mathrm{ml} / \mathrm{kg}+T$. chebula @ 200 mg/ kg; GroupVI: $\mathrm{CCl}_{4}+$ olive oil (1:1,v/v) @ 4 ml/kg + T. belerica @ 100 mg/kg; GroupVII: $\mathrm{CCl}_{4}+$ olive oil (1:1,v/v) @ 4 ml/kg+ T. belerica @ 200 $\mathrm{mg} / \mathrm{kg}$. 
Liver weight (gm)/body weight (100 gm) ratio of all groups has been shown in Table 3. At the end of experiment, the ratio was found significantly $(p<0.05)$ higher in group II and IV, whereas significantly $(p<0.05)$ lowest ratio was observed in group V. Increase in liver size has been reported in hepatosis/hepatitis in rats (Kumar, 2011). On gross examination of liver of rats of positive control group showed mottled appearance with scattered pale and whitey areas attributed to fatty and necrotic changes which are in agreement with observations of other workers (Rai et al., 2001; Chandan et al., 2008). Liver of rats of all four test groups were normal in gross appearance.

Table 3: Liver weight (gm) and liver weight (gm)/body weight (100gm) ratio of different groups of rats (mean $\pm \mathrm{SE})$

\begin{tabular}{|l|c|c|}
\hline Group & Liver weight $(\mathbf{g m})$ & $\begin{array}{c}\text { Liver weight }(\mathbf{g m}) / \mathbf{b o d y} \\
\text { weight }(\mathbf{1 0 0} \mathbf{g m}) \mathbf{r a t i o}\end{array}$ \\
\hline Group I & $8.76 \pm 0.36$ & $4.80 \pm 0.30^{\mathrm{ab}}$ \\
Group II & $8.26 \pm 0.18$ & $5.83 \pm 0.10^{\mathrm{b}}$ \\
Group III & $8.82 \pm 0.25$ & $4.98 \pm 0.18^{\mathrm{ab}}$ \\
Group IV & $8.61 \pm 1.00$ & $5.77 \pm 0.56^{\mathrm{b}}$ \\
Group V & $7.67 \pm 0.78$ & $4.22 \pm 0.32^{\mathrm{a}}$ \\
Group VI & $9.23 \pm 0.25$ & $5.07 \pm 0.16^{\mathrm{ab}}$ \\
Group VII & $9.83 \pm 0.29$ & $5.04 \pm 0.11^{\mathrm{ab}}$ \\
\hline
\end{tabular}

Values bearing different superscripts in the same column differ significantly $(p<0.05)$

Group I: Negative control; Group II: $\mathrm{CCl}_{4}+$ olive oil $(1: 1, \mathrm{v} / \mathrm{v}) @ 4 \mathrm{ml} /$ kg; Group III: $\mathrm{CCl}_{4}+$ olive oil $(1: 1, \mathrm{v} / \mathrm{v}) @ 4 \mathrm{ml} / \mathrm{kg}+$ silymarin @ $5 \mathrm{mg} /$ kg; Group IV: $\mathrm{CCl}_{4}+$ olive oil $(1: 1, \mathrm{v} / \mathrm{v}) @ 4 \mathrm{ml} / \mathrm{kg}+$ T. chebula @ 100 $\mathrm{mg} / \mathrm{kg}$; Group V: $\mathrm{CCl}_{4}+$ olive oil $(1: 1, \mathrm{v} / \mathrm{v}) @ 4 \mathrm{ml} / \mathrm{kg}+$ T. chebula @ $200 \mathrm{mg} / \mathrm{kg}$; GroupVI: $\mathrm{CCl}_{4}+$ olive oil $(1: 1, \mathrm{v} / \mathrm{v}) @ 4 \mathrm{ml} / \mathrm{kg}+$ T. belerica @ $100 \mathrm{mg} / \mathrm{kg}$; GroupVII: $\mathrm{CCl}_{4}+$ olive oil $(1: 1, \mathrm{v} / \mathrm{v}) @ 4 \mathrm{ml} / \mathrm{kg}+T$. belerica@200 mg/kg.

Liver of rats of negative control group was normal and did not show any histopathological changes. The cords of hepatocytes were well preserved, cytoplasm was vacuolated, and sinusoids were well demarcated; no areas of necrosis or no fatty changes were observed (Figure 2). Hepatocytes of rats of positive control group showed severe degenerative changes as well as severe centrilobular fatty changes. The macrovesicular steatosis was seen in most of the hepatocytes and in few places, central vein congestion was noticed (Figure 3). $\mathrm{CCl}_{4}$ is biotransformed by the cytochrome $\mathrm{P}-450$ system to produce the trichloromethyl free radical $\left(\mathrm{CCl}_{3}\right)$, and this further reacts very rapidly with oxygen to yield a highly reactive trichloromethyl peroxy radical $\left(\mathrm{CCl}_{3} \mathrm{O}\right)$ by cytochrome $\mathrm{P}-450$ enzyme (Jia et al., 2011). These free radicals alkylate cellular proteins and other macromolecules to produce lipid and finally result in necrosis of hepatocytes and cell death (Halliwell and Gutteridge, 1990). Pingale (2011) and Gurav (2010) have also reported various degrees of pathological changes starting from centrilobular necrosis of hepatic cells to central lobular fatty degeneration, vacuolations and infiltration of mononuclear inflammatory cells in $\mathrm{CCl}_{4}$ treated rats. Liver of silymarin treated rats (group III) showed normalcy in hepatic cord with mild vacuolar changes (Figure 4). Jain et al. (2008) reported moderate congestion and inflammation in the periportal region of liver sections of silymarin treated animals. Group IV rat's liver showed moderate fatty changes and sinusoids were compressed with distended hepatocyte (Figure 5). In group V, hepatocytes revealed mild degree of fatty changes with early degenerative changes in periportal areas (Figure 6). In contrast to present finding, Tasduq et al. (2006) and Lee et al. (2007) have reported the strong hepatoprotective activity of ethanolic extract of $T$. chebula fruits as it possesses high antioxidant activity (Chang and Lin, 2010). Group VI rat's liver showed moderate degree of pathological changes (Figure 7). In rats, treated with ethanolic extract of fruits of T. belerica @ $200 \mathrm{mg} / \mathrm{kg}$ body weight (group VII), the microscopic pictures were comparable to standard group; and hepatocytes were apparently normal with regenerative changes (Figure 8), suggesting hepatoprotective and hepatoregenerative property, respectively as it prevented the histopathological changes induced by $\mathrm{CCl}_{4}$ and augmented regenerative process that might be due to its antioxidant property (Sabu and Kuttan, 2009; Alam et al., 2011). Jain et al. (2008) reported that liver section of rats treated with ethanolic extract of fruits of $T$. belerica, showed mild congestion, mild inflammation and the overall picture was similar to normal liver.

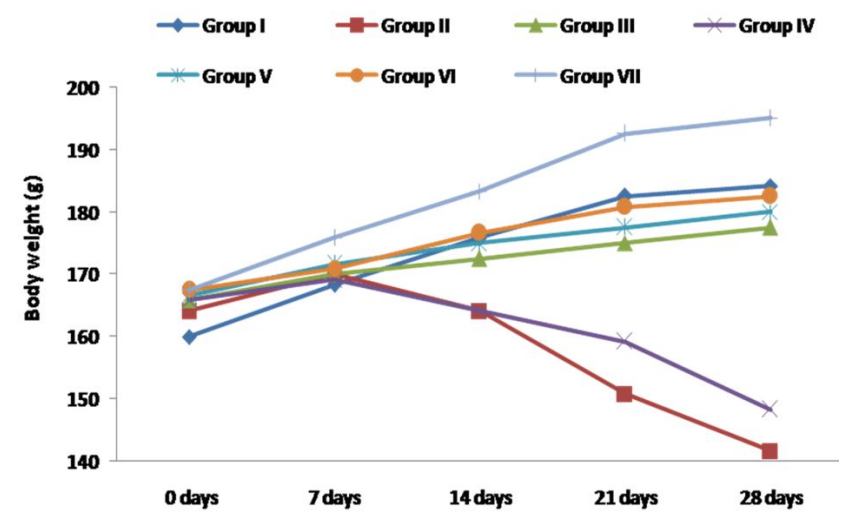

Figure 1: Alteration in body weight $(\mathrm{g})$ in rats received different treatment.

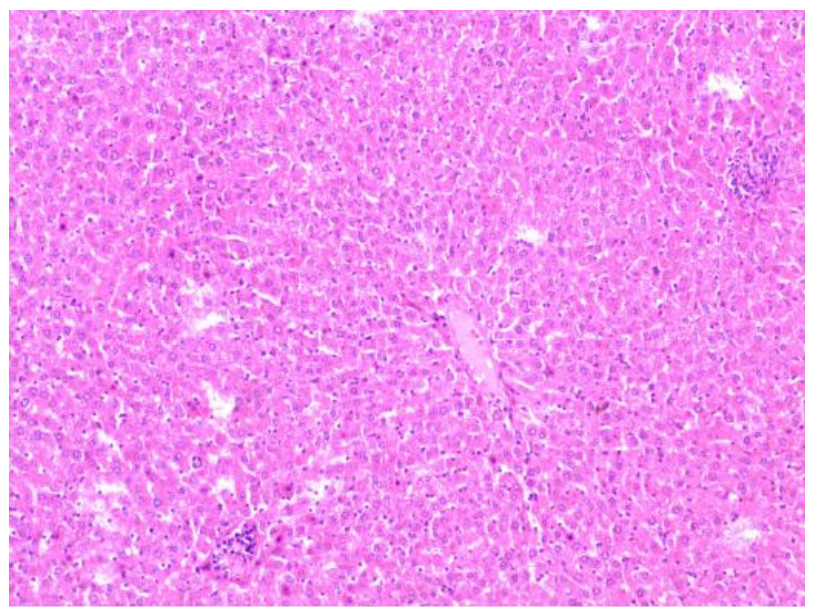

Figure 2: Liver of rats of group I. 


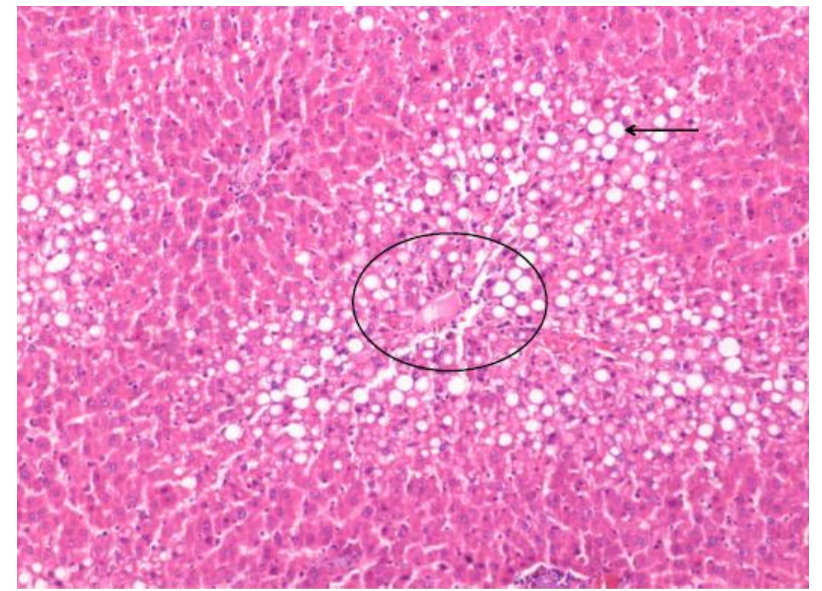

Figure 3: Severe degenerative and centrilobular fatty changes in liver of rats of group II.

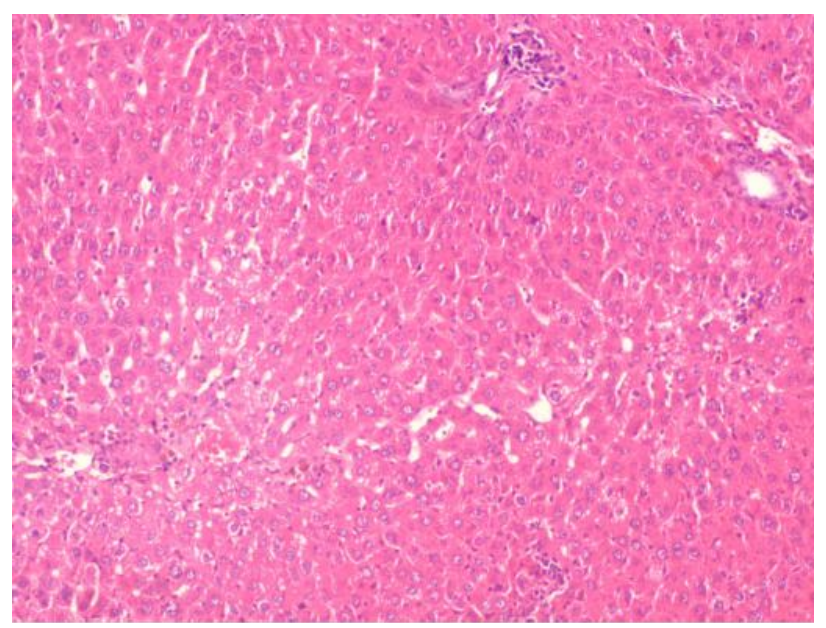

Figure 4: Liver sections of rats of group III.

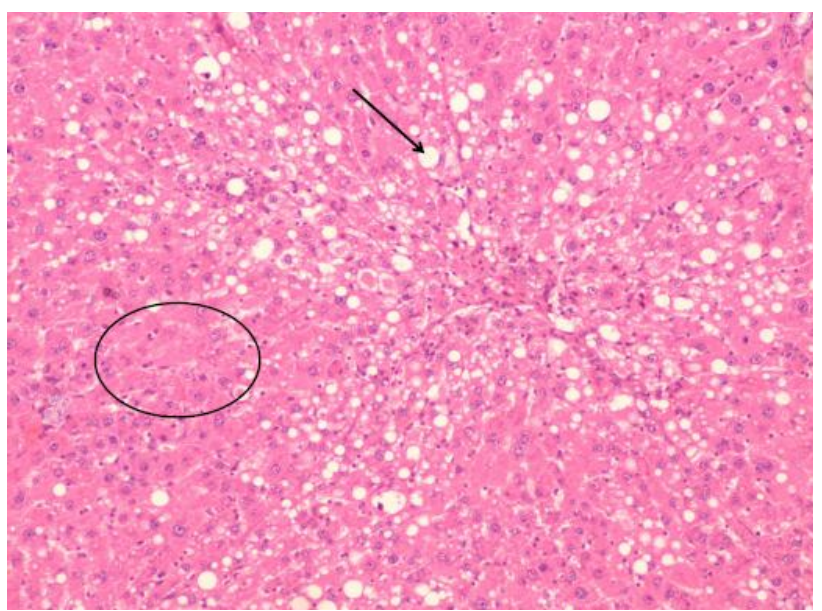

Figure 5: Fatty changes and compressed sinusoids in liver of rats of group IV

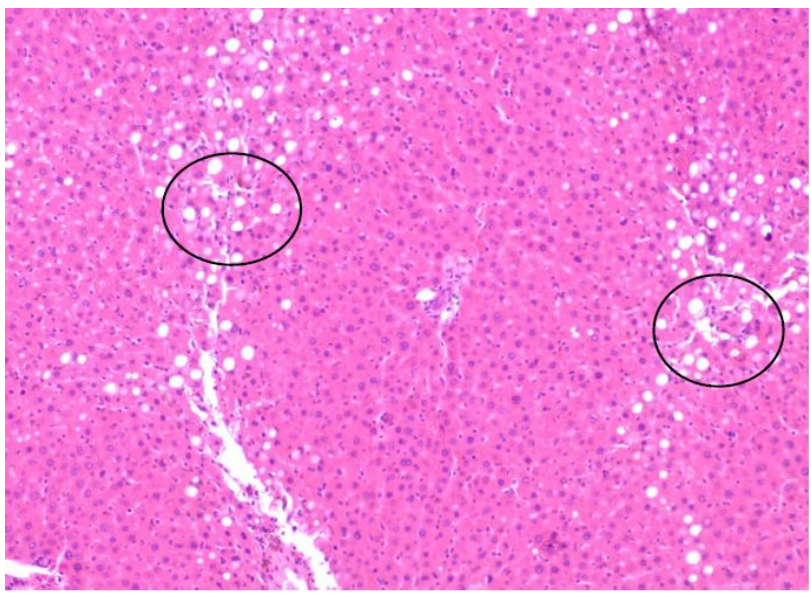

Figure 6: Mild degree of fatty changes and early degenerative changes in periportal areas in liver of rats of group $\mathrm{V}$.

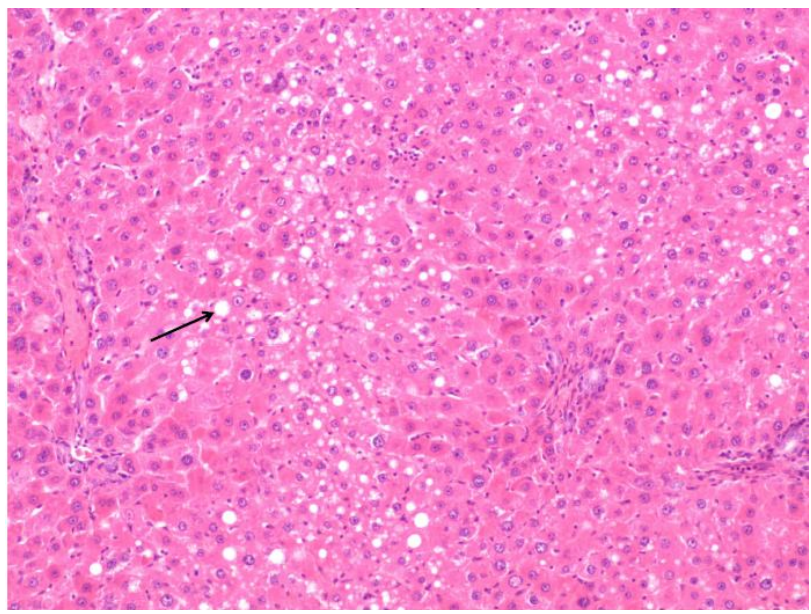

Figure 7: Moderate degree of fatty changes in liver of rats of group VI.

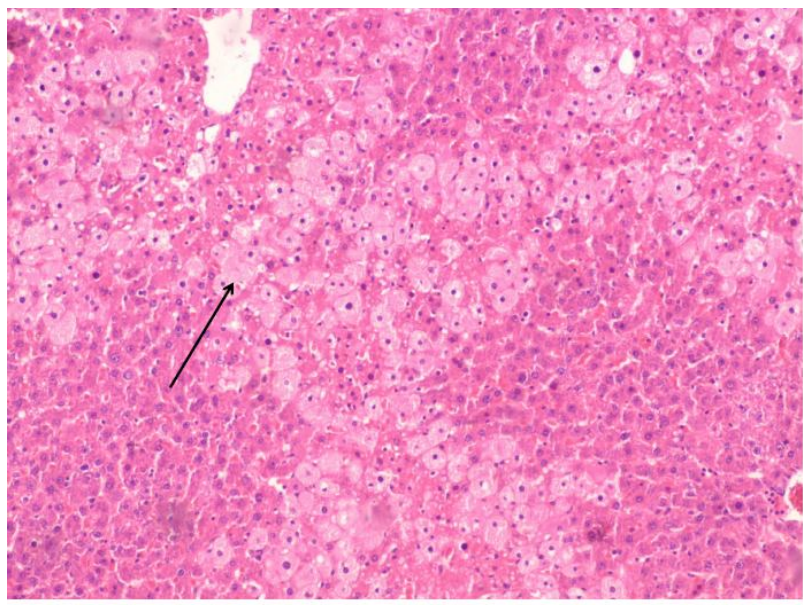

Figure 8: Regenerative changes in liver of rats of group VII 


\section{Conclusion}

The present study revealed that ethanolic extract of T. belerica fruits exhibits better hepatoprotective properties in comparison to that of T. chebula against $\mathrm{CCl}_{4}$ induced hepatotoxicity in rats, seems to validate its use in folk medicine. The rats treated with $T$. belerica fruits extract @ $200 \mathrm{mg} / \mathrm{kg}$ body weight showed significant increase in body weight and their liver's weight as well as volume were lowered significantly. They also showed significantly lowered level of AST, ALT, ALP and total bilirubin, whereas albumin and total protein were significantly increased.

The microscopic picture of rats treated with $T$. belerica fruits extract were comparable to rats treated with silymarin. The hepatocytes were apparently normal with regenerative changes suggesting hepatoprotective and hepatoregenerative property, respectively as it prevented the histopathological changes induced by $\mathrm{CCl}_{4}$ and augmented regenerative process that might be due to its antioxidant property. However, there is a need for further studies regarding its use as natural hepatoprotectant or nutraceutical/pharmaceutical ingredients for patient with compromised liver conditions.

\section{Acknowledgements}

The authors are thankful to the Director ICAR- IVRI, Izatnagar, Uttar Pradesh, India and Indian Council of Agricultural Research, New Delhi for providing the necessary facilities/fund to carry out the study and Centre for Animal Disease Research and Diagnosis, IVRI for providing technical help in histopathological studies. We are thankful to Dr. R.B. Allapur, Department of Botany,Maharashtra Udaygiri Mahavidyalay, Udgir, Maharastra, India for authenticating the plant materials.

\section{Conflict of interest}

We declare that we have no conflict of interest.

\section{References}

Ahsan, M.R.; Islam, K.M.; Bulbul, I.J.; Musaddik, M.A. and Haque, E. (2009), Hepatoprotective activity of methanol extract of some medicinal plants against carbon tetrachloride-induced hepatotoxicity in rats. Eur. J. Sci. Res., 37(2):302-310.

Alam, B.A.; Zahan, R.; Hasan, M.; Khan, M.M.; Rahman, S.M.; Nargis; Chowdhury S. and Haque, E.M. (2011). Antioxidant, antimicrobial and toxicity studies of the different fractions of fruits of Terminalia belerica Roxb, Global J. Pharmacol., 5(1):7-17.

Alhassan, A.J.; Sule, M.S.; Aliyu, S.A. and Aliyu, M.D. (2009). Ideal hepatotoxicity model in rats using carbon tetrachloride $\left(\mathrm{CCl}_{4}\right)$. Bajopas, 2(2):185187.

Ayyanar, M. and Ignacimuthu, S. (2011). Ethnobotanical survey of medicinal plants commonly used by Kani tribals in Tirunelveli hills of Western Ghats in India. J. Ethnopharmacol., 134(3):851-864.

Bone, K. and Mills, S. (2001). Principles and Practices of Phytotheraphy. British J. Phytother., 12(2):107-113.

Chandan, B.K.; Saxena, A.K.; Shukua, S.; Sharma, N.; Gupta, D.K.; Singh, K.; Suri, J.; Bhadauria, M. and Qazi, G.N. (2008). Hepatoprotective activity of Woodfordia fruticosa flowers against carbon tetrachloride induced hepatotoxicity. J. Ethnopharmacol., 119(2):218-224.

Chang, C.L. and Lin, C.S. (2010). Development of antioxidant activity and pattern recognition of Terminalia chebula Retz. extracts and its fermented products. Hung Kuang J. 61:115-129.

Chaterjee, T.K. (2000). Medicinal plants with hepatoprotective properties. In: Herbal Options. 3rd ed. Calcutta Books and Allied (P) Ltd., pp: 135 .
Chattopadhyay, R.R. and Bhattacharyya, S.K. (2007). Terminalia chebula: An update. Phcog. Rev., 1(1):151-156.

Chopra, R.N.; Nayar, S.L. and Chopra, I.C. (1956). Glossary of Indian Medicinal Plants. CSIR, New Delhi, India, pp:106-241.

Culling, C.F.A. (1963). Handbook of histological techniques (including museum techniques). $2^{\text {nd }}$ ed. London, Butterworth, pp:230-248.

Doi, K.; Kurabe, S.; Shimazu, N. and Inagaki, M. (1991). Systemic histopathology of rats with $\mathrm{CCl}_{4}$ - induced hepatic cirrhosis. Lab. Anim., 25:21-25.

Eminzade, S.; Uras, F. and Izzettin, F.V. (2008). Silymarin protects liver against toxic effects of antituberculosis drugs in experimental animals. Nutr. Metab., 5(1):18-26.

Gupta, P.C. (2012). Withania coagulans Dunal: An Overview. Int. J. Pharm. Sci. Rev. Res., 12(2):68-71

Gurav, A.R. (2010). Evaluation of diagnostic markers of hepatopathy and its amelioration by using antioxidant. M.V.Sc. Thesis, Indian Veterinary Research Institute, India.

Halliwell, B. and Gutteridge, J.M., (1990). Role of free radicals and catalytic metal ions in human disease: An overview. Methods Enzymol., 186: $1-85$.

Indian Herbal Pharmacopoeia (2002). Indian Drug Manufacturer's Association, Mumbai, pp:429-438

Jain, R.; Nandakumar, K.; Srivastava, V.; Vaidya, S.K.; Patet,S. and Kumar, P. (2008), Hepatoprotective actvity of ethanolic and aqueous extract of Terminalia belerica in rats. Pharmacologyonline, 2:411-427.

Jia, X.Y.; Zhang, Q.A.; Zhang, Z.Q.; Wang, Y.; Yuan, J.F.; Wang, H.Y. and Zhao, D. (2011). Hepatoprotective effects of almond oil against carbon tetrachloride induced liver injury in rats. Food Chem., 125:673-678.

Joshi, P. and Dhavan, V. (2005). Swertia chirata : An overview. Curr. Sci., 89(4): 635-640.

Kumar, M. (2011). Studies on hepatobilaiary dysfunction along with assessment of therapeutic potential of nutraceuticals. Ph.D. Thesis, Indian Veterinary Research Institute, India.

Kushwaha, N.; Mondal, D.B.; Gupta, V.K. and Jithin, M.V. (2017). Phytochemical analysis and assessment of in vitro antioxidant properties of different plants. J. Pharmacogn. Phytochem., 6(3):123-130.

Lee, H.S.; Jung, S.H.; Yun, B.S. and Lee, K.W. (2007). Isolation of chebulic acid from Terminalia chebula Retz. and its antioxidant effect in isolated rat hepatocytes. Arch. Oxicol., 81(3):211-218.

Majeed, Muhammad (2017). Invited commentary: Evidence-based medicinal plant proudcts for the health care of world population. Ann. Phytomed., 6(1):1-4.

Muriel, P. and Escobar, Y. (2003). Kupffer cells are responsible for liver cirrhosis induced by carbon tetrachloride. J. App. Toxicol., 23(2): 103-108.

Naskar, S.; Mazumder, U.K.; Haldar, P.K. and Ghosh, A. (2011). Evaluation and review of hepatoprotective drugs from natural resources. Pharmacologyonline, 3:993-1006.

Paduraru, I.; Saramet, A.; Danila, G.H.; Nichifor, M.; Jerca, L. and Iacobovici, A. (1996). Antioxidant action of a new flavonic derivative in acute carbon tetrachloride intoxication. Eur. J. Drug. Metab. Pharmacokinet., 21(1):1-6.

Patel, N.; Joseph, C.; Corcoran, G.B. and Ray, S.D. (2010). Silymarin modulates doxorubicin-induced oxidative stress, Bcl-xL and p53 expression while preventing apoptotic and necrotic cell death in the liver. Toxicol. Appl. Pharmacol., 245(2):143-152.

Pingale, S.S. (2011). Hepatoprotective action of Terminalia belerica on $\mathrm{CCl}_{4}$ induced hepatic disorders. Der. Pharma. Chemica., 3(1):42-48.

Podobed, O.V.; Fedorova, L.M.; Iakusheva, I.V.; Abakumova, O.I; Tsvetkova, T.A.; Kovaleva, G.G.; Gavrilchak, A.V. and Shekhter, A.B. (1995). The effect of phosphatidylcholine on repair processes in liver cells in acute $\mathrm{CC}_{4}$ damage. Vopr. Med. Klin., 41(1):13-16. 
Rai, M.; Pai M.R.S.M.; Sabitha, P. and Pai, P. (2001). Hepatoprotective influence of selenium in experimental liver cirrhosis. Kuwait Med. J., 33(4) 333-336.

Ramadan, L.A.; Roushdy, H.M.; Abu Senna, G.M.; Amin, N.E. and El-Deshw, O.A. (2002). Radioprotective effect of silymarin against radiation induced hepatotoxicity. Pharmacol. Res. 45(6):447-454.

Ray, S.D. and Mehendale, H. (1990). Potentiation of $\mathrm{CCL}_{4}$ and $\mathrm{CHCl}_{3}$ hepatotoxixity and lethality by various alcohols. Fundam. Appl. Toxicol., 15(3):429-440.

Rout, S.; Rout, S. and Ghadai, A. (2012). Phytoceutical evaluation and antimicrobial properties of Eclipta alba and Tylophora indica. Int. J. Microbiol. Res., 4(5):227-230.

Sabu, M.C. and Kuttan, R. (2009). Antidiabetic and antioxidant activity of Terminalia belerica Roxb. Indian J. Exp. Biol., 47(4):270-275.
Sarasa, D., Sridhar, S. and Prabakaran, E. (2012). Effect of an antidiabetic extract of Trigonella foenum-graecum on normal and alloxan induced diabetic mice. Int. J. Pharm. Pharm. Sci., 4(1):63-65.

Shanti, A.; Radha, R.; Jayashree, N. and Selvaraj, R. (2010). Pharmacognostic validation of root of Hemidesmus indicus (Linn.) R.Br. J. Chem. Pharm. Res., 2(5):313-322.

Snedecor, G.W. and Cochran, W.G. (1994). Statistical Methods. $8^{\text {th }}$ edn. Ames: Iowa State University Press.

Tasduq, S.A.; Singh, K.; Satti, N.K.; Gupta, D.K. Suri, K.A. and Johri, R.K. (2006). Terminalia chebula (fruit) prevents liver toxicity caused by subchronic administration of rifampicin, isoniazid and pyrazinamide in combination. Hum. Exp. Toxicol., 25(3):111-118.

Ward, F.M. and Daly, M.J. (1999). Hepatic Disease. In: Clinical Pharmacy and Therapeutics (ed. Walker, R. and. Edwards), Churchill Livingstone, New York, USA, pp:195-212. 